\title{
Biogeography and comparative cytogenetics between two populations of Hoplias malabaricus (Bloch, 1794) (Ostariophysi: Erythrinidae) from coastal basins in the State of Bahia, Brazil
}

\author{
Uedson Pereira Jacobina ${ }^{1}$, Paulo Roberto Antunes de Mello Affonso², \\ Paulo Luiz Souza Carneiro² and Jorge Abdala Dergam ${ }^{3}$
}

\begin{abstract}
The species Hoplias malabaricus is a predator fish found in nearly all cis-Andean basins. From a cytogenetic point of view, this species comprises, at least, seven differentiated karyomorphs. Several localities have been formerly analyzed in Brazil, however, some regions, such as Bahia State, remain underrepresented. Recently, the Brazilian Environment Ministry classified both Itapicuru and Contas river basins (entirely located within Bahia territory) as priority conservation areas, whose biodiversity status lacks enough information. Therefore, the goal of the present work was to characterize, cytogenetically, populations of H. malabaricus from both basins, by using conventional staining, Ag-NOR and C-banding techniques. All specimens presented a diploid number of $2 \mathrm{n}=40$ with metacentric/submetacentric chromosomes, without differences between sexes, thereby representing the so-called "karyomorph F". The first metacentric pair presented a remarkably larger size in relation to the other pairs. The NORs were multiple, comprising the terminal region on long arms of two chromosomal pairs in both populations. However, the C-banding pattern was somewhat distinguishable between samples. Although sharing heterochromatic blocks at centromeric region of all chromosomes, the population from Itapicuru River basin appeared to have some more conspicuous blocks than those observed in the population from Contas River basin. The similar karyotype observed in both populations suggests a common geological history between them. The present results represent an advance in the knowledge about the cytogenetic pattern of $H$. malabaricus populations from poorly studied basins.
\end{abstract}

A espécie Hoplias malabaricus é um predador que ocorre em praticamente todas as bacias cis-andinas. Sob o ponto de vista citogenético, ela compreende, pelo menos, sete cariomorfos diferenciáveis. Várias localidades já foram previamente analisadas no Brasil, porém, algumas regiões, como o Estado da Bahia, permanecem pouco amostradas. Recentemente, o Ministério de Meio Ambiente classificou as bacias do rio Itapicuru e Contas (inteiramente localizadas na Bahia), como áreas prioritárias de conservação, cuja biodiversidade carece de informações suficientes. Neste sentido, o objetivo do presente trabalho foi caracterizar citogeneticamente populações de H. malabaricus nessas bacias, por meio de técnicas de coloração convencional, Ag-RON e bandamento C. Todos os espécimes e populações analisadas apresentaram número diploide $2 \mathrm{n}=40$ com cromossomos metacêntricos/submetacêntricos, sem diferenças entre os sexos, representando assim o denominado "cariomorfo F”. O primeiro par metacêntrico apresentou tamanho notavelmente maior que os demais pares. As RONs foram múltiplas, ocupando a região terminal do braço longo de dois pares cromossômicos em ambas populações. Entretanto, os padrões de heterocromatina foram relativamente diferenciáveis entre as bacias hidrográficas estudadas. Apesar de compartilharem blocos heterocromáticos na região centromérica de todos os cromossomos, a população da bacia do Itapicuru apresentou alguns blocos mais conspícuos em relação aos da bacia do rio de Contas. O cariótipo similar encontrado em ambas as populações parece indicar uma história geológica em comum. Os dados obtidos representam um avanço no conhecimento dos padrões citogenéticos de populações de $H$. malabaricus provenientes de bacias pouco estudadas.

Key words: Fish, Karyomorphs, Brazilian coastal rivers, Geographic distribution.

\footnotetext{
${ }^{1}$ Departamento de Biologia Celular e Genética, Centro de Biociências, Universidade Federal do Rio Grande do Norte. Natal, RN, Brazil. uedsonbio@gmail.com

${ }^{2}$ Departamento de Ciências Biológicas, Universidade Estadual do Sudoeste da Bahia. Av. José Moreira Sobrinho, s/n., 45206-510 Jequié, BA, Brazil. paulomelloaffonso@yahoo.com.br

${ }^{3}$ Departamento de Biologia Animal, Universidade Federal de Viçosa. Viçosa, MG, Brazil. dergam@ufv.br
} 


\section{Introduction}

The Neotropical region is known as one of the most diversified areas in number of freshwater fish species worldwide (Schaefer, 1998). However, the mechanisms responsible for such diversity are still poorly understood. In Brazil, the coastal drainages represent important biogeographic zones, characterized by a high level of endemism in ichthyofauna. Phylogenetic analyses of many fish taxa suggest a close relationship among the rivers flowing to the Atlantic Ocean, a pattern that is supported by the tectonic history of the crystalline shield (Ribeiro, 2006). Coupled with the putative effects caused by the glaciations, several hypotheses have been formulated to explain the occurrence of related species in these coastal Brazilian basins (Menezes, 1988; Weitzman et al., 1988; Beheregaray et al., 2002). Widespread species are potentially informative to analyze and understand the historical relationships among these basins. The fish Hoplias malabaricus (Bloch, 1974) is a good example of a widely distributed species suitable for continental-scale and biogeographical studies within South American basins. This generalist predator is found in virtually all cis-Andean hydrographic systems, from Panamá to Colorado River, in Argentina, representing the most widespread representative of the family Erythrinidae (Oyakawa, 2003). Apparently related to a typical sedentary behavior, the populations of $H$. malabaricus are characterized by a remarkable karyotypic diversity, comprising seven basic karyomorphs with variation on both chromosomal number and morphology and distinct sex chromosomes systems as well (Bertollo et al., 2000).

Over 35 distinct localities have been sampled for cytogenetic studies in H. malabaricus, most of them in Brazil. Some populations have also been sampled in Argentina, Uruguay and Suriname (Bertollo et al., 2000). However, several Brazilian regions, mainly in Northeast, still need further sampling. The State of Bahia is the largest one in the Northeastern region, which shows a paucity of cytogenetic studies on fish species. Several important basins, restricted to the state range, are found in Bahia, such as Contas and Itapicuru River basins. Both drainages occur in the Caatinga (dry bushwood) biome and comprise several seasonal rivers. Little is known about the fish fauna of these regions (Rosa, 2004; Santos \& Zanata, 2006) and the Brazilian Environment Ministry recently regarded these basins as major areas for conservation, classified as "sites lacking enough information” (MMA, 2006). These areas were selected because of their species richness, high endemism and the possible occurrence of threatened species (Silva, 2002). Furthermore, over the last decades, these basins, like many others in Brazil, have been constantly affected by human activities such as mineral exploitation, urban pollution, habitat modifications by water impoundment and introduction of exotic species, all considered major causes of extinction in native freshwater fish (Hilsdorf \& Petrere, 2002; Santos \& Zanata, 2006; Trindade \& Jucá-Chagas, 2008).

Therefore, the goal of the present work was to characterize cytogenetically populations of $H$. malabaricus from Contas and Itapicuru basins in the State of Bahia, in order to determine their karyotypic organization and carry out a comparative analysis between both populations. The data are discussed under a biogeographic context, providing new information about this species in the Neotropical region.

\section{Material and Methods}

A total of 30 specimens of Hoplias malabaricus were analyzed. Twenty-three individuals (6 males and 17 females) were from Contas River basin (main channel, Preto do Costa River and Boa Nova Lake). Seven specimens (3 males and 4 females) were collected from the main river channel in the Itapicuru River basin (Fig. 1). Voucher specimens (MZUFV 3614, MZUFV 3615, UJ01, UJ02, UJO3, UJ04) were deposited in the collection of the Museu de Zoologia João Moojen de
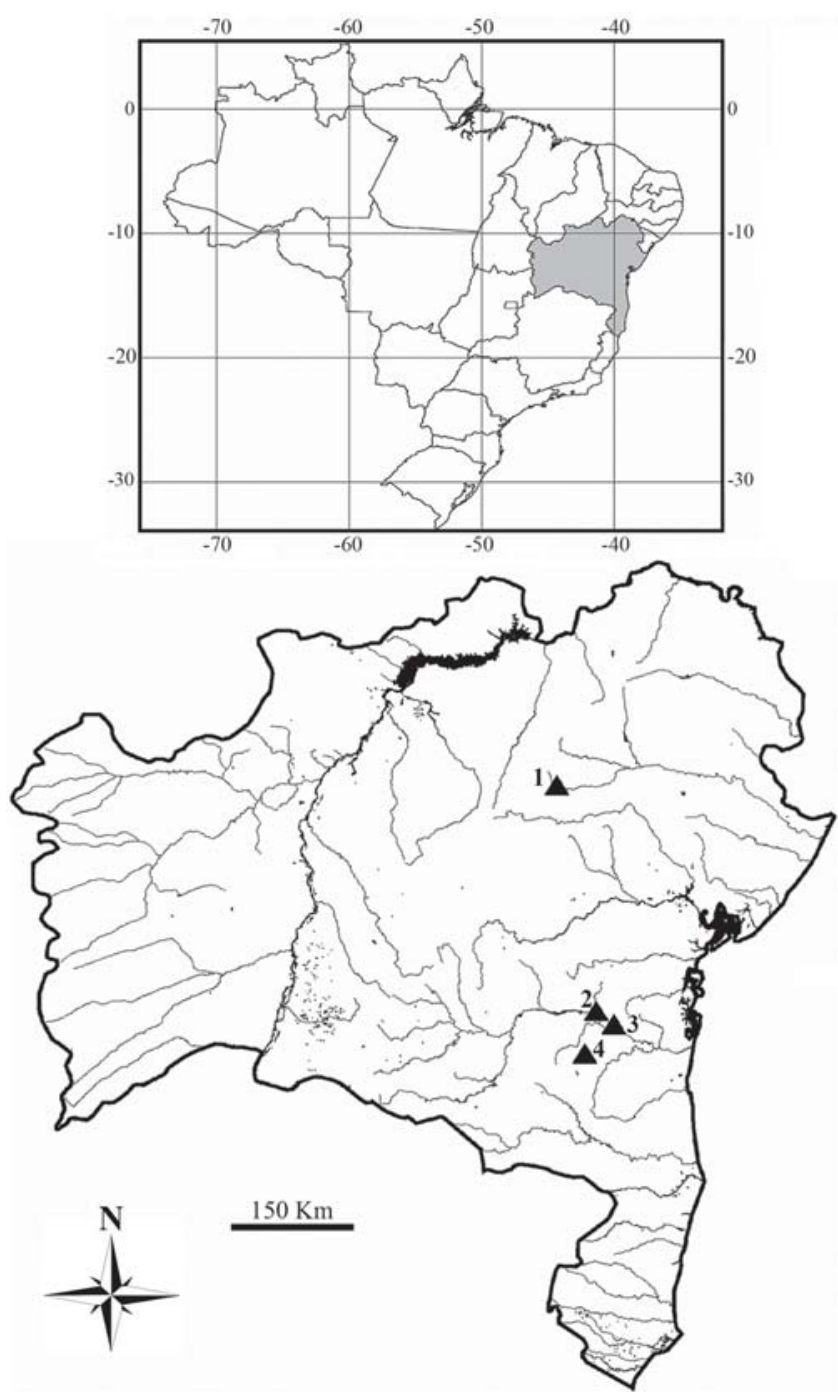

Fig. 1. Contas and Itapicuru River basins (BA). The triangles indicate the collection sites in the following rivers: 1 -

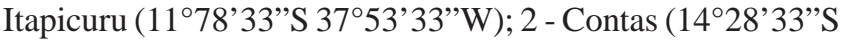
$\left.39^{\circ} 01^{\prime} 67^{\prime \prime} \mathrm{W}\right)$; 3 - Preto do Costa (1401'67’S 39॰88’33”W); and 4 - Boa Nova Lake (14³6'67’S 40¹6’67’'W). 
Oliveira, Departamento de Biologia Animal, Universidade Federal de Viçosa.

Cell division was stimulated 48h prior to cytogenetic procedures by inoculation of Munolan ${ }^{\circledR}$, as described by Molina (2001). The mitotic chromosomes were obtained from anterior kidney cells, according to Bertollo et al. (1978). The distribution of constitutive heterochromatin was analyzed by C-banding (Sumner, 1972) with slight modifications (barium hydroxide at $42^{\circ} \mathrm{C}$ for $1 \mathrm{~min}$ ). The detection of active nucleolar organizer regions was obtained by silver nitrate staining (Howell \& Black, 1980). The chromosomal morphology was established based on arm ratio (AR), following Levan et al. (1964), where the chromosomes were classified as metacentric $(\mathrm{M}, \mathrm{AR}=1.00$ - 1.69) and submetacentric $(\mathrm{SM}, \mathrm{AR}=1.70$ 2.99). The software Easydio ${ }^{\circledR}$ version 1.0 was used to build the ideogram (Diniz \& Xavier, 2006).

\section{Results}

Based on Giemsa staining, all analyzed specimens were similar. Samples from both river basins presented a diploid number of $2 n=40$, with metacentric and submetacentric chromosomes, without differences between males and females (Fig. 2). The first metacentric chromosomal pair was remarkably larger than the others. Active NORs in populations from Contas and Itapicuru river basins were located at telomeric regions of two chromosomal pairs, characterizing a multiple NOR system (Fig. 2).

Whereas both samples presented C-positive heterochromatin at the centromeric region of all chromosomal pairs, some more conspicuous C-bands were evident in the population from Itapicuru River, as those on the chromosomal pairs 7, 9 and 12 in the karyotype (Fig. 3). In order to provide a better comparison between the two populations, a preliminary idiogram representative of each sample is shown in Fig. 4.

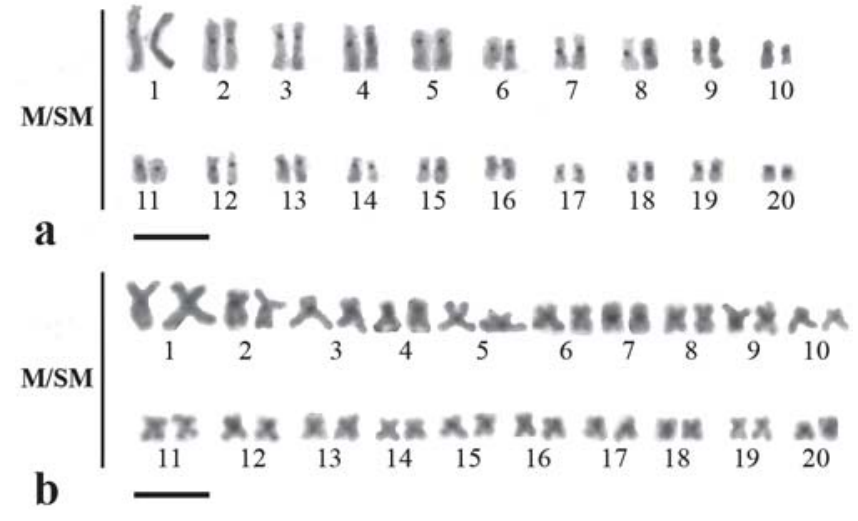

Fig. 3. C-banded karyotypes of Hoplias malabaricus from Contas River basin (a) and Itapicuru River basin (b). Bar = $10 \mu$.

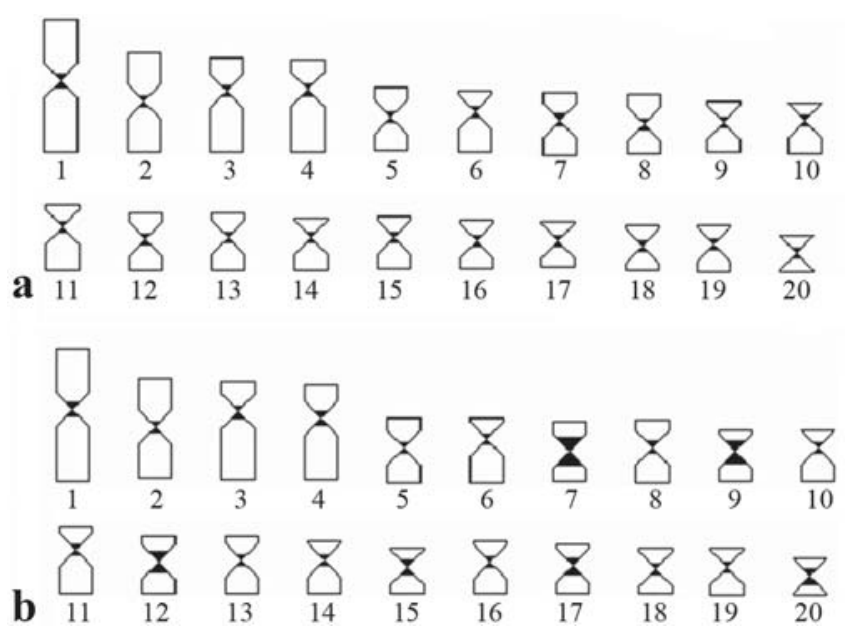

Fig. 4. Comparative ideogram between Hoplias malabaricus populations from Contas River (a) and Itapicuru River (b) basins.

\section{Discussion}

\section{Cytogenetic features}

Several karyomorphs have been identified in $H$. malabaricus, with diploid numbers ranging from $2 n=39$ to $2 n=42$, including structural variation and distinct sex chromosome systems. Coupled with the detection of sympatric karyomorphs and no hybrid forms, these results suggest $H$. malabaricus should be regarded as a species complex (Bertollo et al., 1997; Bertollo et al., 2000).

The karyotypes herein described for Contas and Itapicuru river basins samples correspond to karyomorph $\mathrm{F}$, as proposed by Bertollo et al. (2000). Such karyomorph has been found from Suriname to Minas Gerais, including Northeastern Brazil. Besides lacking evident sex chromosomes, it can be diagnosed by the first chromosomal pair, which is much larger than in other karyomorphs bearing the same diploid number (Bertollo et al., 2000). This feature was also observed in the populations
Fig. 2. Giemsa-stained karyotypes of Hoplias malabaricus from Contas River basin (a) and Itapicuru River basin (b): The NOR-bearing pairs are shown in detail. $\mathrm{Bar}=10 \mu$. 
from Contas and Itapicuru river basins, both displaying a remarkable large first metacentric pair.

The presence of multiple telomeric NORs is also commonly reported in H. malabaricus (Bertollo, 1996; Born \& Bertollo, 2000; Vicari et al., 2003; Vicari et al., 2006) and in other erythrinids as well (Diniz \& Bertollo, 2003), although the location of major ribosomal sites may vary inter- and intraindividually, including both telomeres of a same chromosome (bitelomeric NOR) or else on the X chromosome (Bertollo, 1996; Born \& Bertollo, 2000; Diniz \& Bertollo, 2003; Vicari et al., 2003, 2006). Thus, the multiple Ag-NOR pattern observed in $H$. malabaricus from Contas and Itapicuru river basins (telomeric region on two chromosomal pairs) agrees with previous data for other $H$. malabaricus.

The constitutive heterochromatin is usually associated with gene inactivity or late replication DNA, being commonly found on centromeres and telomeres, or interspersed with NORs (Sumner, 2003). Heterochromatin can play a key role in the karyotypic evolution of fish, mainly related to identification of polymorphisms, either at intra-population (e.g., Astyanax scabripinnis, Mantovani et al., 2000) or inter-population levels, such as in $H$. malabaricus from Tibagi and Iguaçu rivers (Vicari et al., 2003) and Leporinus elongatus from Upper Paraná river basin (Molina et al., 2008). In general, $H$. malabaricus present C-positive heterochromatin at the centromeric regions of all chromosomes and over telomeres in a few pairs. The pattern of C-bands distribution detected in the samples of the present study was similar to that reported for other populations of $H$. malabaricus (Dergam \& Bertollo, 1990; Haaf et al., 1993; Bertollo et al., 1997), with the predominant occurrence on the centromeres of all chromosomes. The more conspicuous heterochromatic bands that appear to occur in the population from Itapicuru River basin may indicate a certain degree of genetic differentiation between both populations analyzed, probably due to mechanisms of heterochromatin dispersal (Schweizer \& Loidl, 1987) or by multiple replication and accumulation steps (John, 1988).

\section{Biogeographic pattern}

The Eastern coastal drainages of Brazil and their freshwater fish fauna represent an important and poorly understood area of biogeographic interest because of their high endemism level (Vari \& Weitzman, 1990; Ribeiro, 2006). Nearly $96 \%$ of the 285 fish species listed by Bizerril (1994) are endemic to this region.

Formerly, the Eastern coast basins have been divided into three major groups: 1- Eastern region of Bahia; 2- Southeastern region, from Espírito Santo to São Paulo; 3- Southern region from Paraná to Rio Grande do Sul (data from Agência Nacional das Águas - ANA, available at www.ana.gov.br). However, such subdivision is controversial, especially when considered the distribution range of some fish groups. The identification of several endemic fish species within these regions suggests that there might be other biogeographic units or even subprovinces along such areas (Bizerril, 1994; Ribeiro, 2006).
The cytogenetic reports in the H. malabaricus complex reinforce that the sub-division pattern along Eastern basins is much more intricate than initially proposed. Three out of the seven karyomorphs described by Bertollo et al. (2000) are found in coastal Brazilian basins: the karyomorph A, widely distributed over several Brazilian basins, also reaching Uruguay and northern Argentina ; the karyomorph B, restricted to Doce River basin; and the karyomorph F, identified along Northeastern Brazil, besides some basins up to Northern region. Molecular data in $H$. malabaricus from coastal basins identified two distinct patterns, being one restricted to Northern region and another to Southern of the Abrolhos platform, in the State of Bahia, which could act as a geographic barrier to the dispersal of coastal fishes (Pereira, 2005). Coupled with the successive and long-term range of cladogenetic events that have taken place between coastal drainages and the crystalline shield (Ribeiro, 2006), these data might explain the occurrence of the karyomorph F on the Eastern portion of the Brazilian territory.

Moreover, the similar karyotypic pattern observed in the present work indicates that both Itapicuru and Contas river basins would share a common evolutionary origin. Similar evidence was found through genetic studies in samples of Astyanax aff. bimaculatus from Contas and Recôncavo Sul basins, in Bahia (Pamponet et al., 2008). According to Costa \& Inda (1982), a great fracture in the crystalline rocks gave rise to proterozoic basins that actually cover parts of Bahia, Goiás and Minas Gerais States. Although representing a very ancient event, the occurrence of some basal groups, such as the Trichomycteridae catfish (genus Trichogenes) in both Paraguaçu basin and Southeastern Brazil (Pinna, 1998), typically exemplifies their close evolutionary relationship.

Other multiple and successive vicariant events, like uplifting, shortening and enlargement of tectonic plates have affected the continental margins and might have favored either the splitting or the connectivity of several adjacent basins (Lundberg et al., 1998). Associated with this evolutionary scenario, the Pleistocene movements, like the sea retreats during glacial periods, could have dispersed the fish fauna from nearby but formerly independent drainages through the formation of large lagoon-like regions in the river mouth. As an opposite force, the sea transgression over the continent would lead to the separation among previously connected populations, thereby fostering their allopatric diversification (e. g., Beheregaray et al., 2002). Such balanced model between dispersal and vicariance has often been claimed to explain the diversity in the Neotropical fish fauna, although it is thought to be poorly efficient to understand the species diversification over longer separation periods (Weitzman \& Weitzman, 1982; Lundberg et al., 1998).

\section{Final remarks}

The synchronization among biological and geological processes are likely to provide the source and hence the best way to understand the historic biogeographic pattern in the Neotropical region. The evidence of similar trends based on distinct data, such as cytogenetic variation and 
geomorphological events can reliably support hypotheses about the evolutionary footprints in the ichthyofauna from the coastal basins of Brazil. The species complex $H$. malabaricus, widespread over nearly all Brazilian river systems, has been regarded as a good evolutionary model of geographic differentiation. The results from the present study are the first genetic report in populations of $H$. malabaricus from Bahia State, encompassing the Caatinga biome (semiarid climate), thereby expanding the data about the distribution of the karyomorph $\mathrm{F}$ along Brazilian hydrographic basins. The basins located in the semi-arid region have been historically overlooked and their fish diversity has been underestimated for a long time. Actually, as long as the researches increase, a high endemism level has been identified in fish species from these areas as, for instance, in the family Rivulidae (Rosa, 2004). However, few detailed studies about the aquatic biota over semi-arid regions in Brazil are available and most basins remain poorly known. Furthermore, such hydrographic systems are constantly threatened by human activities and several species are already at risk (Silva, 2002; Rosa, 2004; MMA, 2006). Although H. malabaricus is not considered a threatened species, the preliminary data related to heterochromatin content suggest a certain degree of genetic differentiation between populations from Itapicuru and Contas river basins. In this sense, it is important that this population divergence be confirmed, not only by additional C-banding, but also by using complementary chromosomal markers. This confirmation will be important to regard Itapicuru and Contas Rivers as unique conservation units in order to avoid the biodiversity losses caused by antropic influences.

\section{Acknowledgements}

The authors would like to thank Mr. Henrique Batalha Filho for the assistance on the map figure. Financial support to this work was provided by FAPESB, UESB and UFV.

\section{Literature Cited}

Affonso, P. R. A. M., V. S. Miranda, A. S. Medrado, U. P. Jacobina, J. A. Bitencourt, J. S. Almeida \& P. L. Carneiro. 2007. Light microscopy and the case of neotropical fish. Pp. 370-377. In: Mendez-Vilas, A. \& J. Diaz (Eds.). Modern Research and Educational Topics in Microscopy. Badajoz, Formatex, 1033p.

Beheregaray, L. B., P. Sunnucks \& D. A. Briscoe. 2002. A rapid fish radiation associated with the last sea level changes in southern Brazil: the silverside Odontesthes perugiae complex. Proceeding of the Royal Society of London B, 269(1486): 65-73.

Bertollo, L. A. C. 1996. The nucleolar organizer regions of Erythrinidae fish. An uncommon situation in the genus Hoplias. Cytologia, 61(1): 75-81.

Bertollo, L. A. C., G. G. Born, J. A. Dergam, A. S. Fenocchio \& O. Moreira-Filho. 2000. A biodiversity approach in the neotropical Erythrinidae fish, Hoplias malabaricus. Karyotypic survey, geographic distribution of cytotypes and cytotaxonomic considerations. Chromosome Research, 8: 603613.
Bertollo, L. A. C., O. Moreira-Filho \& M. S. Fontes. 1997. Karyotypic diversity and distribution in Hoplias malabaricus (Pisces, Erythrinidae): Cytotypes with $2 \mathrm{n}=40$ chromosomes. Brazilian Journal of Genetics, 20(2): 237-242.

Bertollo, L. A. C., C. S. Takahashi \& O. Moreira-Filho. 1978. Cytotaxonomic considerations on Hoplias lacerdae (Pisces, Erythrinidae). Brazilian Journal of Genetics, 1: 103-120.

Bizerril, C. R. S. F. 1994. Análise taxonômica e biogeográfica da ictiofauna de água doce do leste do Brasil. Acta Biologica Leopoldensia, 16(1): 51-80.

Born, G. G. \& L. A. C. Bertollo. 2000. An XX/XY sex chromosome system in a fish species, Hoplias malabaricus with a polymorphic NOR-bearing X chromosome. Chromosome Research, 8: 111-118.

Costa, L. M \& H. A. Inda. 1982. O aulacógeno do Espinhaço. Ciências da Terra, 2: 13-18.

Dergam, J. A. \& L. A. C. Bertollo. 1990. Karyotypic diversification in Hoplias malabaricus (Osteichthyes, Erythrinidae) of São Francisco and Alto Paraná basins, Brazil. Revista Brasileira de Genética, 13(4): 755-766.

Diniz, D. \& L. A. C. Bertollo. 2003. Karyotypic studies on Hoplerythrinus unitaeniatus (Pisces, Erythrinidae) populations. A biodiversity analysis. Caryologia, 56: 303-313.

Diniz, D. \& P. M. Xavier. 2006. Easy Idio. Available from: http:// geocities.yahoo.com.br/easyidio/

Haaf, T., M. Schmid, C. Steinlein, P. M. Galetti Jr. \& H. F. Willard. 1993. Organization and molecular cytogenetics of satellite DNA family from Hoplias malabaricus (Pisces, Erythrinidae). Chromosome Research, 1(1): 77-86.

Hilsdorf, A. W. \& M. Petrere Jr. 2002. Conservação de peixes na Bacia do rio Paraíba do Sul. Ciência Hoje, 30(180): 62-65.

Howell, W. M. \& D. A. Black. 1980. Controlled silver-staining of nucleolus organizer regions with a protective colloidal developer: a 1-step method. Experientia, 36: 1014-1015.

John, B. 1988. The biology of heterochromatin. Pp. 1-147. In: Verma, R. S. (Ed.). Heterochromatin: molecular and structural aspects. New York, Cambridge University Press, 320p.

Levan, A., K. Fredga \& A. A. Sandberg. 1964. Nomenclature for centromeric position on chromosomes. Hereditas, 52: 201220.

Lundberg, J. G., L. G. Marshall, J. Guerrero, B. Horton, M. C. S. L. Malabarba \& F. Wesselingh. 1998. The stage for neotropical fish diversification: A history of tropical South America rivers. Pp.13-48. In: Malabarba, L. R., R. E. Reis, R. P. Vari, Z. M. S. Lucena \& C. A. S. Lucena (Eds.). Phylogeny and Classification of Neotropical Fishes. Porto Alegre, Edipucrs, 603p.

Mantovani, M., L. D. S. Abel, C. A. Mestriner \& O. Moreira-Filho. 2000. Accentuated polymorphism of heterochromatin and nucleolar organizer regions in Astyanax scabripinnis (Pisces, Characidae): tools for understanding Karyotypic evolution. Genetica, 109: 161-168.

Menezes, N. A. 1988. Implications of the distribution patterns of the species of Oligosarcus (Teleostei, Characidae) from central and southern South America. Pp. 295-304. In: Vanzolini, P. E. \& W. R. Heyer (Eds.). Proceedings of Workshop on Neotropical Distribution Patterns. Rio de Janeiro, Academia Brasileira de Ciências, 488p.

MMA - Ministério do Meio Ambiente. 2006. Caderno da região hidrográfica Atlântico Leste. Brasília, Ministério do Meio Ambiente, Secretaria de Recursos Hídricos, 156p.

Molina, W. F. 2001. An alternative method for mitotic stimulation in fish cytogenetics. Chromosome Science, 5: 149-152. 
Molina, W. F., O. Shibatta \& P. M. Galetti Jr. 2008. Chromosomal evidence of population subdivision in the freshwater fish Leporinus elongatus in the Upper Paraná River basin. Genetics and Molecular Biology, 31(1): 270-274.

Oyakawa, O. T. 2003. Family Erythrinidae (Trahiras). Pp. 238240. In: Reis, R. E., S. O. Kullander \& C. J. Ferrari Jr. (Eds.). Check List of the Freshwater Fishes of South and Central America. Porto Alegre, Edipucrs, 729p.

Pamponet, V. C. C., P. L. S. Carneiro, P. R. A. M. Affonso, V. S. Miranda, J. C. Silva Junior, C. G. Oliveira \& F. A. Gaiotto. 2008. A multi-approach analysis of the genetic diversity in populations of Astyanax aff. bimaculatus Linnaeus, 1758 (Teleostei, Characidae) from Northeastern Brazil. Neotropical Ichthyology, 6(4): 621-630.

Pereira, T. L. 2005. Divergência genômica e filogeografia de traíras Hoplias malabaricus (Bloch, 1794) (Teleostei: Erythrinidae) na costa leste do Brasil. Unpublished MSc. Dissertation, Universidade Federal de Viçosa, Viçosa, 74p.

Pinna, M. C. C. 1998. Phylogenetic relationships of neotropical Siluriforms: historical overview and synthesis of hypotheses. Pp. 279-330. In: Malabarba, L. R., R. E. Reis, R. P. Vari, Z. M. S. Lucena \& C. A. S. Lucena (Eds.). Phylogeny and Classification of Neotropical Fishes. Porto Alegre, Edipucrs, 603p.

Ribeiro, A. C. 2006. Tectonic history and the biogeography of the freshwater fishes from the coastal drainages of eastern Brazil: an example of faunal evolution associated with a divergent continental margin. Neotropical Ichthyology, 4(2): 225-246.

Rosa, R. S. 2004. Diversidade e conservação dos peixes da caatinga. Pp. 149-161. In: Silva, J. M. C., M. Tabarelli, M. T. Fonseca \& L. V. Lins (Eds.). Biodiversidade da Caatinga: Áreas e Ações Prioritárias para a Conservação. Brasília, Ministério do Meio Ambiente, 382p.

Santos, A. C. A. \& A. M. Zanata. 2006. Peixes no semi-árido brasileiro. Pp. 97-102. In: Queiroz, L. P., A. Rapini \& A. M. Giulietti (Eds.). Rumo ao Amplo Conhecimento da Biodiversidade do Semi-árido Brasileiro. Brasília, Ministério da Ciência e Tecnologia, 144p.

Schaefer, S. A. 1998. Conflict and resolution: impact of new taxa on phylogenetic studies of the neotropical cascudinhhos (Siluroidei: Loricariidae). Pp. 375-400. In: Malabarba, L. R., R. E. Reis, R. P. Vari, Z. M. S. Lucena \& C. A. S. Lucena (Eds.). Phylogeny and Classification of Neotropical Fishes. Porto Alegre, Edipucrs, 603p.

Schweizer, D. \& J. Loidl. 1987. A model for heterochromatin dispersion and the evolution of $\mathrm{C}$ band patterns. Chromosome Today, 9: 61-74.

Silva, J. M. C. 2002. Caatinga, Biota Aquática. Pp. 142-143. In: Maury, C. M. (Ed.). Biodiversidade Brasileira: Avaliação e identificação de áreas e ações prioritárias para conservação, utilização sustentável e repartição dos benefícios da biodiversidade nos biomas brasileiros. Brasília, Ministério do Meio Ambiente, 404p.

Sumner, A. T. 1972. A simple technique for demonstrating centromeric heterochromatin. Experimental Cell Research, 75: 304-306.

Sumner, A. T. 2003. Chromosomes: organization and function. London, Blackwell Publishing, 287p.

Trindade, M. E. J. \& R. Jucá-Chagas. 2008. Diet of two serrasalmin species, Pygocentrus piraya and Serrasalmus brandtii (Teleostei: Characidae), along a stretch of the rio de Contas, Bahia, Brazil. Neotropical Ichthyology, 6(4): 645-650.

Vari, R. P. \& S. H. Weitzman. 1990. A review of the phylogenetic biogeography of the freshwater fishes of South America. Pp. 381-393. In: Peters, G. \& R. Hutterer (Eds.). Vertebrates in the tropics. Bonn, Museum Alexander Koening, 424p.
Vicari, M. R., R. F. Artoni \& L. A. C. Bertollo. 2003. Heterochromatin polymorphism associated with $18 \mathrm{~S}$ rDNA. A differential pathway among Hoplias malabaricus fish populations. Animal Cytogenetics and Comparative Mapping, 101: 24-28.

Vicari, M. R., R. F. Artoni \& L. A. C. Bertollo. 2006. Comparative cytogenetics of Hoplias malabaricus (Pisces, Erythrinidae): A population analysis in adjacent hydrographic basins. Genetics and Molecular Biology, 28: 103-110.

Weitzman, S. H., N. A. Menezes \& M. J. Weitzman. 1988. Phylogenetic biogeography of the Glandulocaudini (Teleostei: Characiformes: Characidae) with comments on the distribution of other freshwater fishes in eastern and southeastern Brazil. Pp. 379-427. In: Vanzolini, P. E. \& W. R. Heyer (Eds.). Proceedings of Workshop on Neotropical Distribution Patterns. Rio de Janeiro, Academia Brasileira de Ciências, 488p.

Weitzman, S. H. \& M. Weitzman. 1982. Biogeography and evolutionary diversification in Neotropical freshwater fishes, with comments on the refuge theory. Pp. 403-422. In: Prance, T. G. (Ed.). Biological Diversification in the Tropics. New York, Columbia University Press, 714p.

Accepted September 7, 2009

Published December 18, 2009 